UDK 631.963:632.51

Naučni rad-Scientific paper

\title{
Distribution of economically important weed species in the riparian and roadside vegetation of Serbia
}

\author{
Ana Anđelković ${ }^{*}$, Goran Tmušić ${ }^{2}$, Dragana Marisavljevićna ${ }^{1}$, Mladen Marković ${ }^{3}$, Dušanka \\ Cvijanović ${ }^{2}$, Goran Anačkov², Snežana Radulovićé, Danijela Pavlović1 \\ ${ }^{1}$ Institute for Plant Protection and Environment, Teodora Drajzera 9, Belgrade, Serbia \\ ${ }^{2}$ University of Novi Sad, Faculty of Sciences, Department of Biology and Ecology, Trg Dositeja \\ Obradovića 3, Novi Sad, Serbia \\ ${ }^{3}$ PE Roads of Serbia, Department for Environmental Protection, Bulevar kralja Aleksandra 282, \\ Belgrade, Serbia \\ *email: ana.andjelkovic21@gmail.com
}

\section{SUMMARY}

Transportation corridors such as waterways and road networks serve as an entranceway for invasive and economically important weed species. The unstable environment of riparian areas and nutrient enrichment of road verges promotes the establishment and spread of these species, which may have a negative effect on nearby arable land, leading to severe yield reductions. We aimed to register the presence and frequency of five selected weed species (Chenopodium album, Cirsium arvense, Convolvulus arvensis, Cynodon dactylon, and Lactuca serriola) within these linear corridors. Sites along waterways were visited during 2013-2016, and road networks during 2018-2019. At each site, studied weed species were registered along $100 \mathrm{~m}$ transects, resulting in 250 localities along waterways and 180 near road networks. The most frequent species is $C$. arvensis, followed by L. serriola and C. album, while less prevalent species are $C$. arvense and $C$. dactylon. The main characteristic of studied species is their preference for roadside habitats, except for Chenopodium album, which is more common in riparian areas.

Keywords: dispersal corridor, weeds, roads, waterways, Serbia. 


\section{INTRODUCTION}

Waterways, roads and railways are critical in the spread of invasive and allergenic plants, but also of economically important weed species (Burkart, 2001; Cottet et al., 2020). River systems are among essential natural corridors (Naiman et al., 1993; Naiman and Decamps, 1997) since water flow in rivers and canals connects the surrounding habitats, thus enabling a rapid dispersal of plant propagules (Johansson et al., 1996). Riparian vegetation consists of various vegetation types (Naiman et al., 1993). Dominant riparian vegetation types depend on the regional climate, soil characteristics, species pool and hydrological, geomorphological, and disturbance regimes on the local and regional level (Richardson et al., 2007). Despite the fact that riparian habitats provide a wide array of ecosystem services (Xiang et al., 2017; Riis et al., 2020), they are constantly exposed to a plethora of anthropogenic pressures (Burkart, 2001; Stella and Bendix, 2019), making them into critical conduits of plant dispersal (Arredondo et al., 2018). Some of the well-known examples of the spread of invasive plants along riparian corridors are: Amorpha fruticosa (Radovanović et al., 2017), Arundo donax (Fernandes et al., 2013), Impatiens glandulifera (Pyšek and Prach, 1995), Paspalum distichum (Aguiar et al., 2005) and Reynoutria spp. (Gerber et al., 2008).

Similar to waterways, road infrastructure greatly intensifies the introduction and spread of pioneer, ruderal and invasive plants into new areas (Reed et al., 2020). Increasing the biogeographic connectivity of previously geographically disconnected regions (Liu et al., 2019) leads to dramatic changes in historical land use (Laurance and Arrea, 2017). Roads act as colonization corridors that facilitate the movement of species, connecting isolated suitable seed-source habitats (Benedetti and Morelli, 2017; Vanneste et al., 2020), thus promoting the spread of many weed species (Christen and Matlack, 2008; Benedetti and Morelli, 2017). In addition to serving as dispersal routes, road verges may also provide a suitable secondary habitat for many plant species (Wehling and Diekmann, 2009; Auestad et al., 2011). Furthermore, frequent and intensive disturbances characteristic for riparian and roadside habitats have led these linear landscape features to become the hotspots of diversity and sources of spread for many highly competitive, rapidly colonizing, generalist plant species (Vanneste et al., 2020).

Chenopodium album L., Cirsium arvense (L.) Scop., Convolvulus arvensis L., Cynodon dactylon (L.) Pers. and Lactuca serriola L. are widespread weeds in row and grain crops in Serbia. Additionally, they are often found in vegetable crops, orchards, vineyards, on lawns, in boundary strips, on fallow fields and in ruderal habitats in Serbia (Vrbničanin et al., 2008a, b). They produce vast amounts of propagules, with their seeds retaining viability in the soil for many years (Funes et al., 1999), while C. arvense, C. arvensis, C. dactylon are perennial and reproduce vegetatively. Many studies worldwide have proven their economic importance for agriculture, i.e. the severe yield reductions in a number of important crops worldwide (Weaver et al., 2006; Yarnia, 2010; Valizadeh and Birshekari, 2011; Dodamani and Das, 2013; Bajwa et al., 2019; Chadha et al., 2019; Safdar et al., 2019). Recently, Meseldžija et al. (2020) reported the yield losses in soybean production in Serbia, as an aftermath of weed infestations of the studied weed species. Although these species are native to the territory of Serbia, recent studies have 
shown that both alien and native species can display high negative impacts on the diversity and richness of species in case they dominate the plant communities (Hejda et al., 2021).

Consequently, owing to the economic importance of the five selected weed species for the agricultural production in Serbia, and knowing the importance of rivers, canals, and roads in the long-distance dispersal of plants, our research aimed to determine the distribution and degree of presence of $C$. album, C. arvense, C. arvensis, C. dactylon and L. serriola along these linear dispersal corridors.

\section{MATERIAL AND METHODS}

Field research in riparian areas was conducted during the 2013-2016 period in the summer months. A total of 250 field sites were studied along six canals of the Danube-Tisa-Danube system and 39 rivers. Vegetation data were collected within $100 \mathrm{~m}$ long transects, which were parallel to the water flow, on the bank of the studied river/canal.

Roadside fieldwork was done during the summer and early autumn period of 2018-2019. A total number of 180 field sites were visited along the highways (IA category) and IB category of state roads in Serbia. Mapping of the selected weed species was done along $100 \mathrm{~m}$ vegetation transects, positioned parallel to the road, on the road verge and the downwards slope by the road.

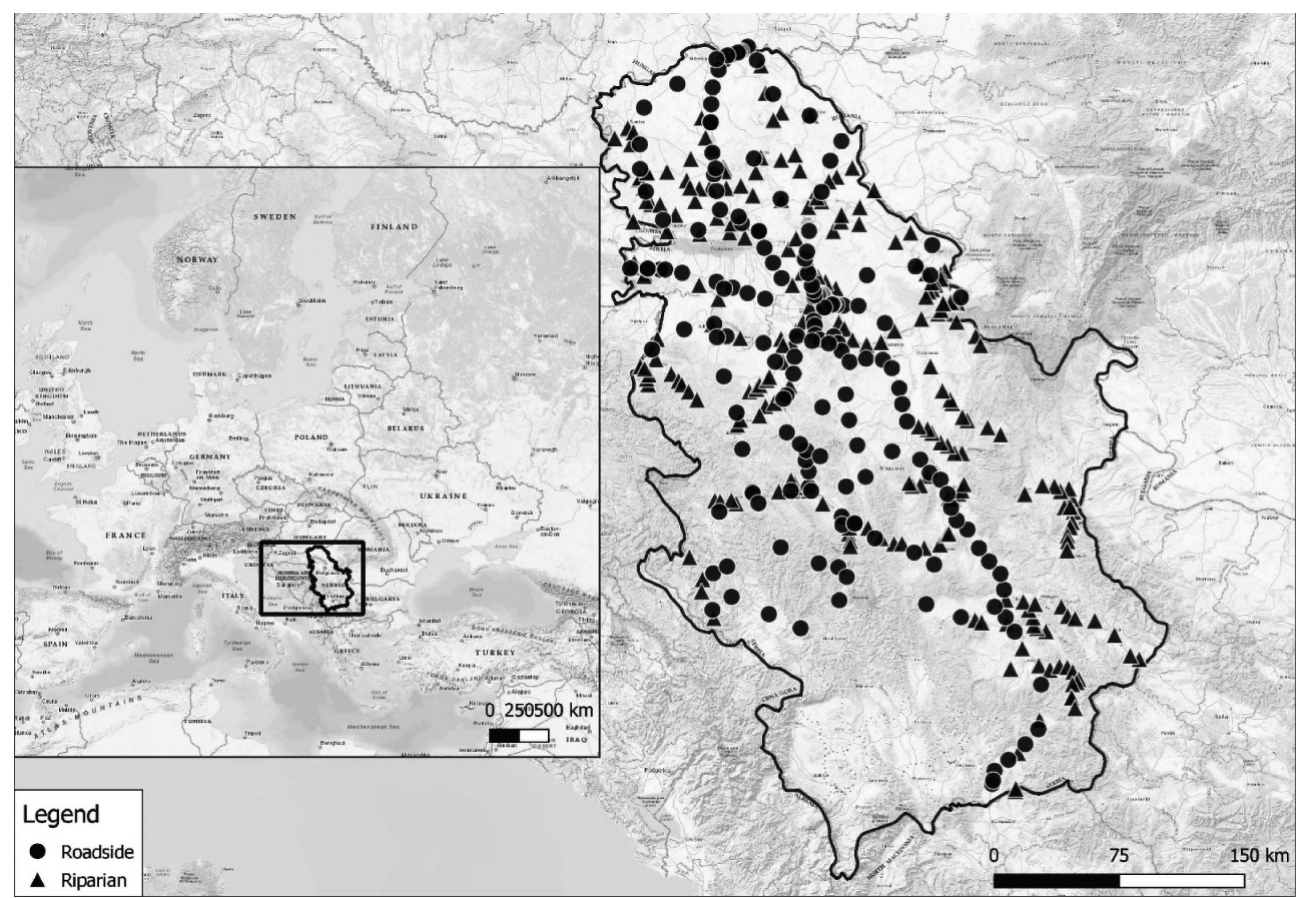

Map 1. Map of Serbia showing all the studied field sites.

Karta 1. Mapa Srbije koja prikazuje sve istraživane lokalitete. 
Presence data were georeferenced using a hand-held Garmin GPS eTracker, while the cover and abundance of the selected species were recorded in percentages (\%) of the species cover on the observed transect (Kent, 2012). Selection of the field sites meant to attain the optimal area coverage and the most unified geographical distribution/resolution of the obtained results (Map 1).

\section{RESULTS AND DISCUSSION}

Alien invasions and vast expansions of native plant species could represent a significant threat for biodiversity conservation. In order to support biodiversity conservation actions, it is necessary to adopt appropriate measures, not only for the control and prevention of negative effects of invasive species, but also of dominant native weeds (Hejda et al., 2021). Consequently, all data on the distribution and spread of common agricultural weed species is valuable. The total number of records of the studied weed species documented along the river and road networks of Serbia is presented in Table 1, while their distribution across riparian zones of different catchment areas of Serbia is given in figure 1.

Table 1. An overview of records of the studied weed species found along the riparian and roadside field sites of Serbia.

Tabela 1. Pregled broja nalaza istraživanih korovskih vrsta registrovanih na riparijalnim i lokalitetima duž puteva u Srbiji.

\begin{tabular}{lccc}
\hline \multirow{2}{*}{ Weed species } & \multicolumn{2}{c}{ Field site type } & Total number of \\
& roadside & riparian & records \\
\hline Chenopodium album & 62 & 105 & 167 \\
Cirsium arvense & 102 & 50 & 152 \\
Convolvulus arvensis & 151 & 85 & 236 \\
Cynodon dactylon & 97 & 10 & 107 \\
Lactuca serriola & 83 & 85 & 168 \\
\hline
\end{tabular}

Of the five selected weed species, $C$. arvensis is the most common (Table 1), with 151 records in roadside vegetation and 85 in riparian zones. While this species has been recorded across all catchment areas of Serbia (except for the Aegean Sea Basin; Figure 1), its presence in the roadside vegetation is primarily characteristic for highways and IB category state roads with more intensive road traffic (Map 2). The frequent presence of $C$. arvensis along these roads can be explained by stronger propagule pressure, resulting from higher traffic volume (RødEriksen et al., 2020).

L. serriola and C. album have been recorded at 168 and 167 field sites, respectively (Table 1). The results (Table 1, Map 3) have shown that while the presence of L. serriola is equally characteristic for both riparian and roadside vegetation (86 and 83 records, respectively), 


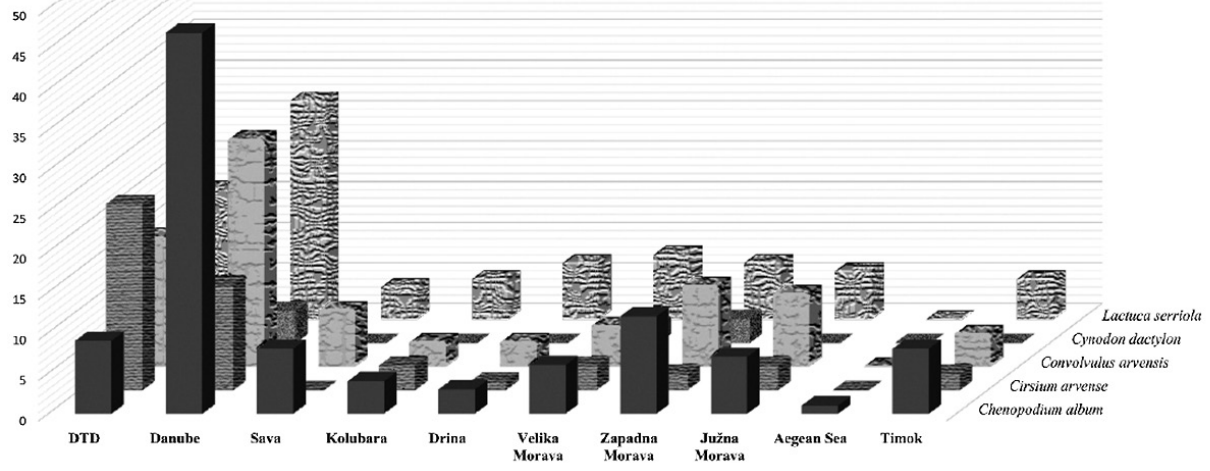

* DTD stands for the Danube-Tisa-Danube canal system.

Figure 1. Number of records of the studied weed species across riparian field sites of different catchment areas. Grafik 1. Broj nalaza istraživanih korovskih vrsta u riparijalnim zonama različitih slivova.

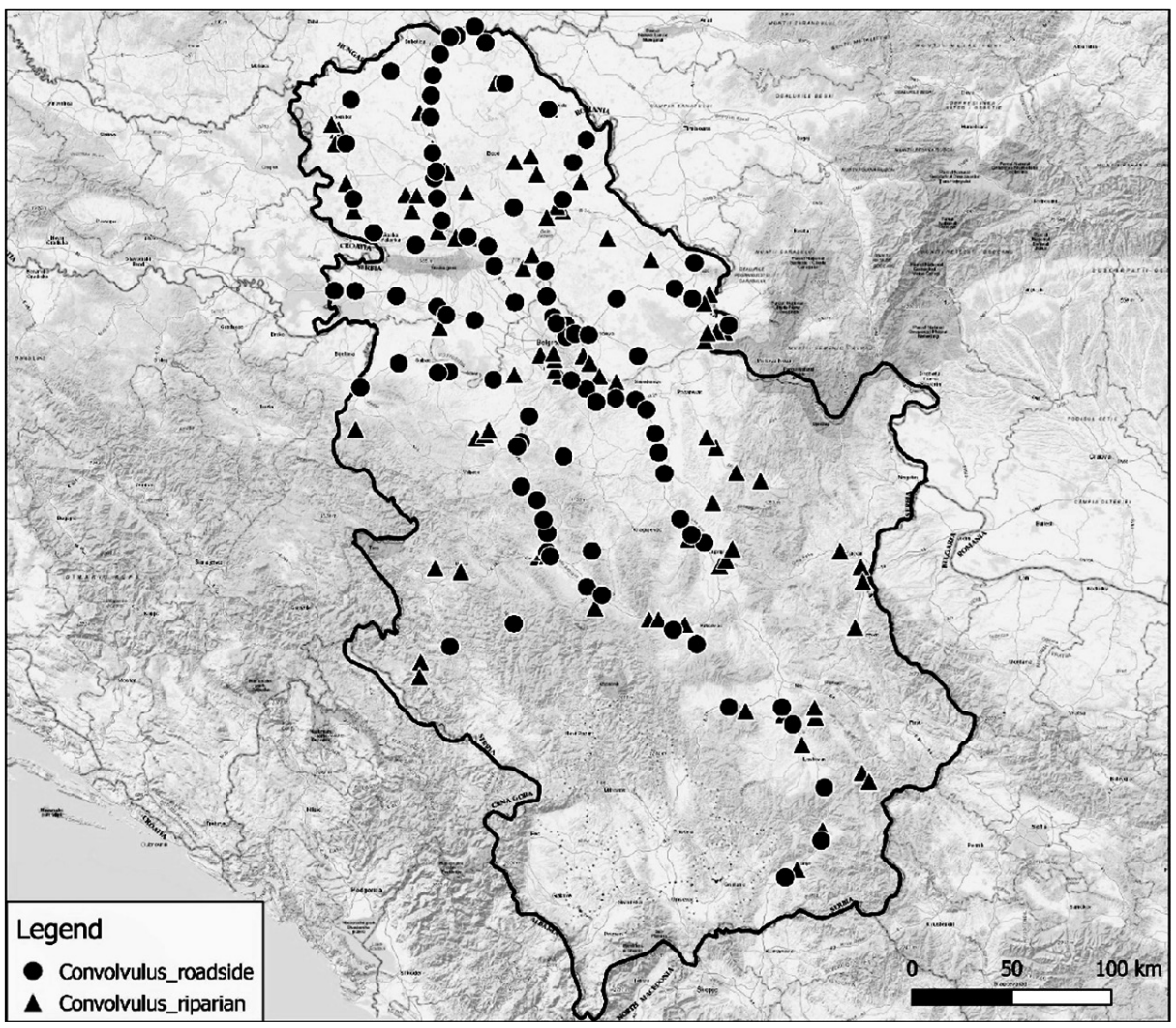

Mep 2. Distribution map of Convolvulus arvensis along the roads and riparian zones of Serbia. Karta 2. Mapa distribucije Convolvulus arvensis duž puteva i riparijalnih područja Srbije. 
C. album has mostly been documented in the riparian vegetation (63\% records). It is predominantly present along the rivers belonging to the Danube, Zapadna Morava, and Timok catchment areas and the Danube-Tisa-Danube canal network (Figure 1). Meanwhile, its roadside distribution is primarily characteristic for the territory of Vojvodina (Map 4). Such distribution of $C$. album could be ascribed to its ecological preferences, as it is a typical ruderal and segetal species, preferring nitrophilous habitats (Slavnić, 1972). This is also line with ecological indices (Kojić et al., 1997) of this weed species, which show its preference for moderately dry $(\mathrm{V}=2), \mathrm{pH}$ neutral $(\mathrm{K}=3)$, meso- to eutrophic $(\mathrm{N}=4)$, moderately sunny $(\mathrm{S}=$ $3)$ and warm $(\mathrm{T}=3)$ sites.

Unlike C. album, C. arvense is more frequent in the roadside vegetation (67\% records), recorded at a total of 152 field sites (Table 1, Map 5). Compared to other studied species, which have shown a stronger prevalence for the riparian vegetation of the Danube catchment area rivers, $C$. arvense has predominantly been found in the riparian vegetation of the DanubeTisa-Danube canal system (Figure 1), where it has been recorded at $70 \%$ of the studied field

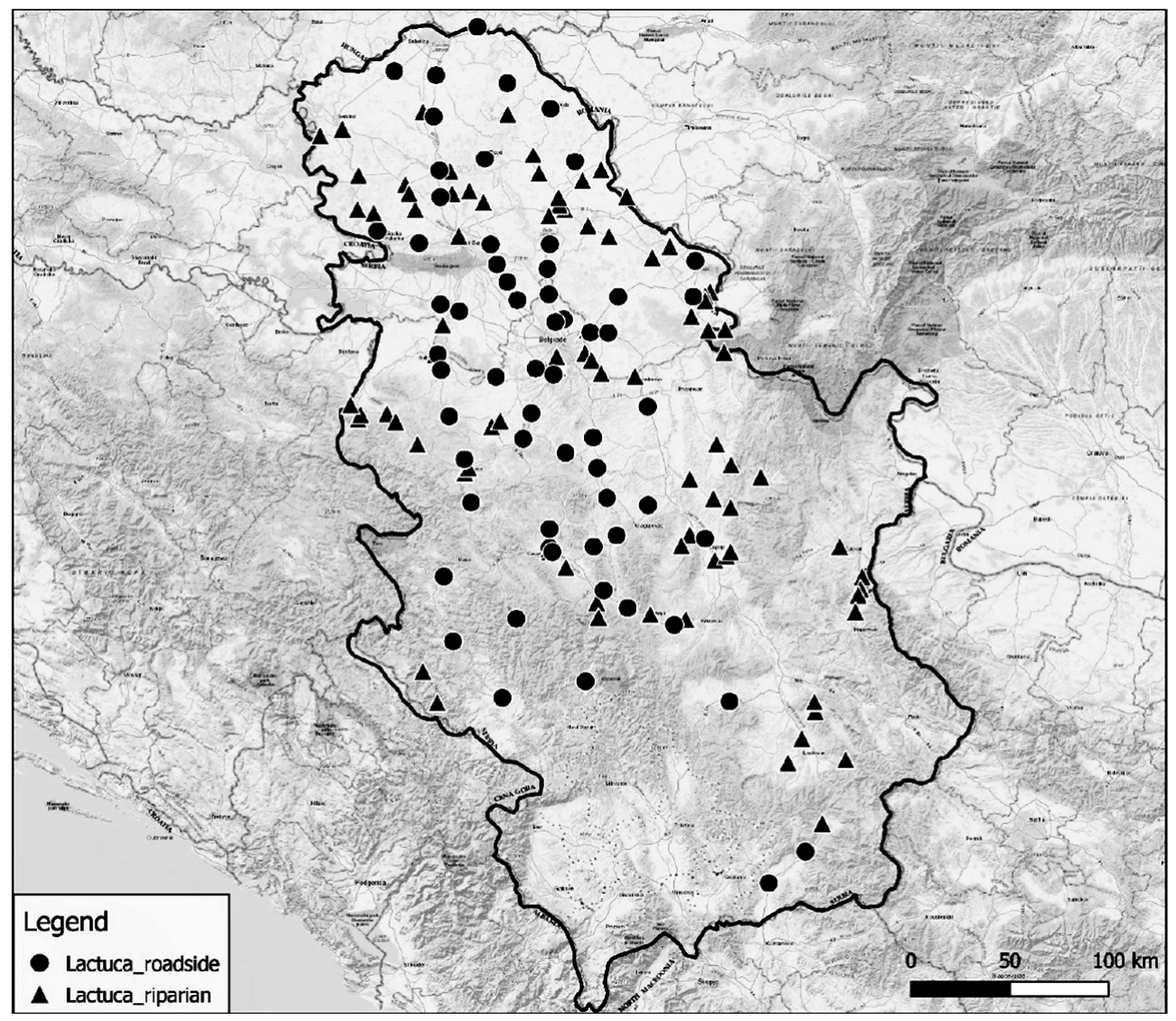

Map 3. Distribution map of Lactuca serriola along the roads and riparian zones of Serbia. Karta 3. Mapa distribucije Lactuca serriola duž puteva i riparijalnih područja Srbije. 


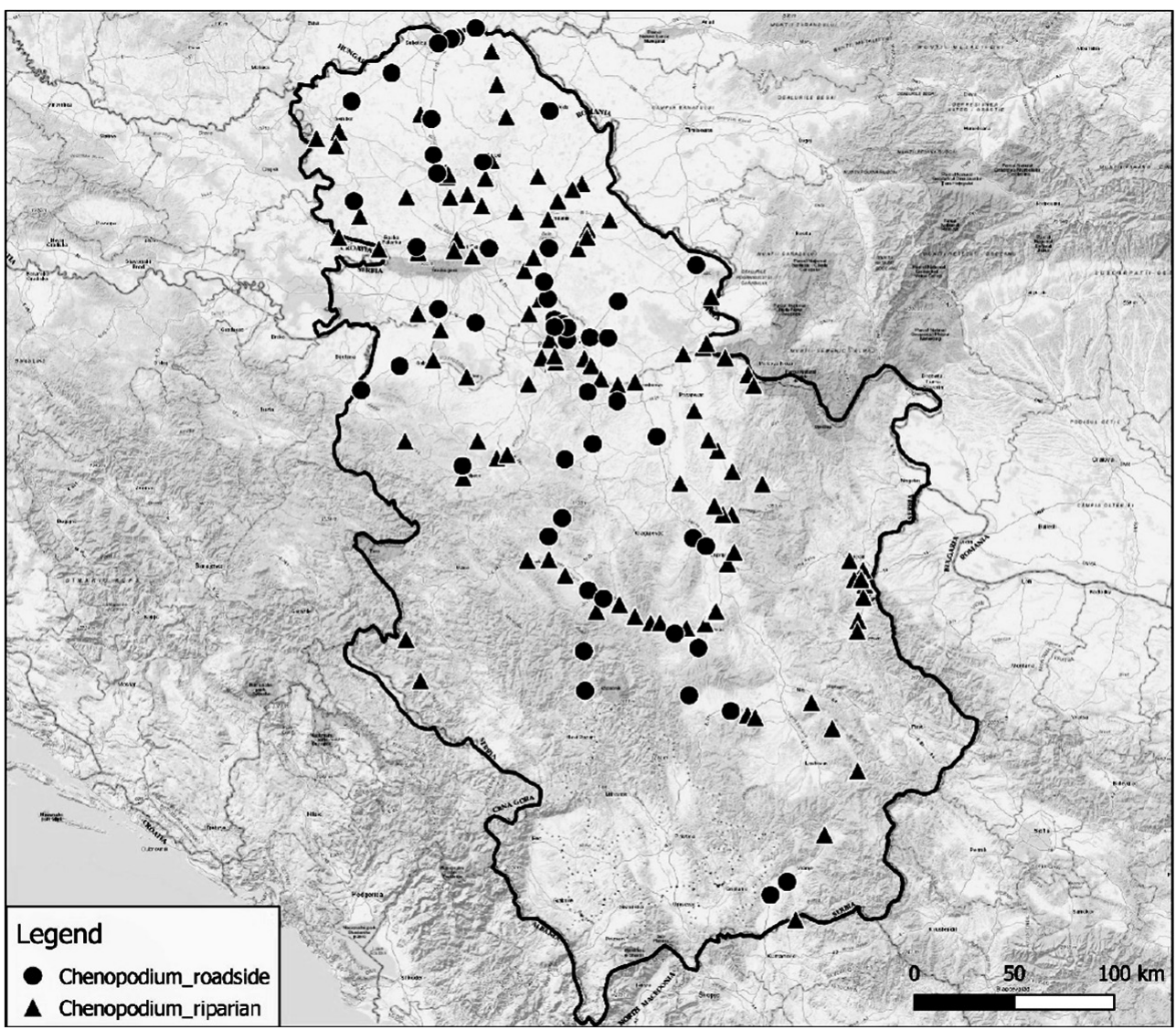

Map 4. Distribution map of Chenopodium album along the roads and riparian zones of Serbia. Karta 4. Mapa distribucije Chenopodium album duž puteva i riparijalnih područja Srbije.

sites. A high incidence of this weed species in both riparian and ruderal roadside habitats can be attributed to its invasiveness. Weidlich et al. (2020) highlight genus Cirsium as the one containing some of the most invasive plants worldwide. Although $C$. arvense is native to Serbia, its invasive behaviour enables it to successfully outcompete other native species and consequently become dominant in such habitats which experience strong disturbances and high nutrient influx (Aude et al., 2004).

Finally, C. dactylon was documented within fewer field sites, compared with other studied species (Table 1). Records show that this weed species is predominantly present in the roadside vegetation (91\% records), with highways marked as its main corridors of its spread/dispersal (Map 6). Such a strong prevalence of $C$. dactylon in the roadside vegetation could be linked to previous findings showing that grassland generalist species, such as $C$. dactylon, are positively affected by the specific edaphic conditions on road verges, following the management regime and disturbance frequencies (Jakobsson et al., 2018). These conditions 


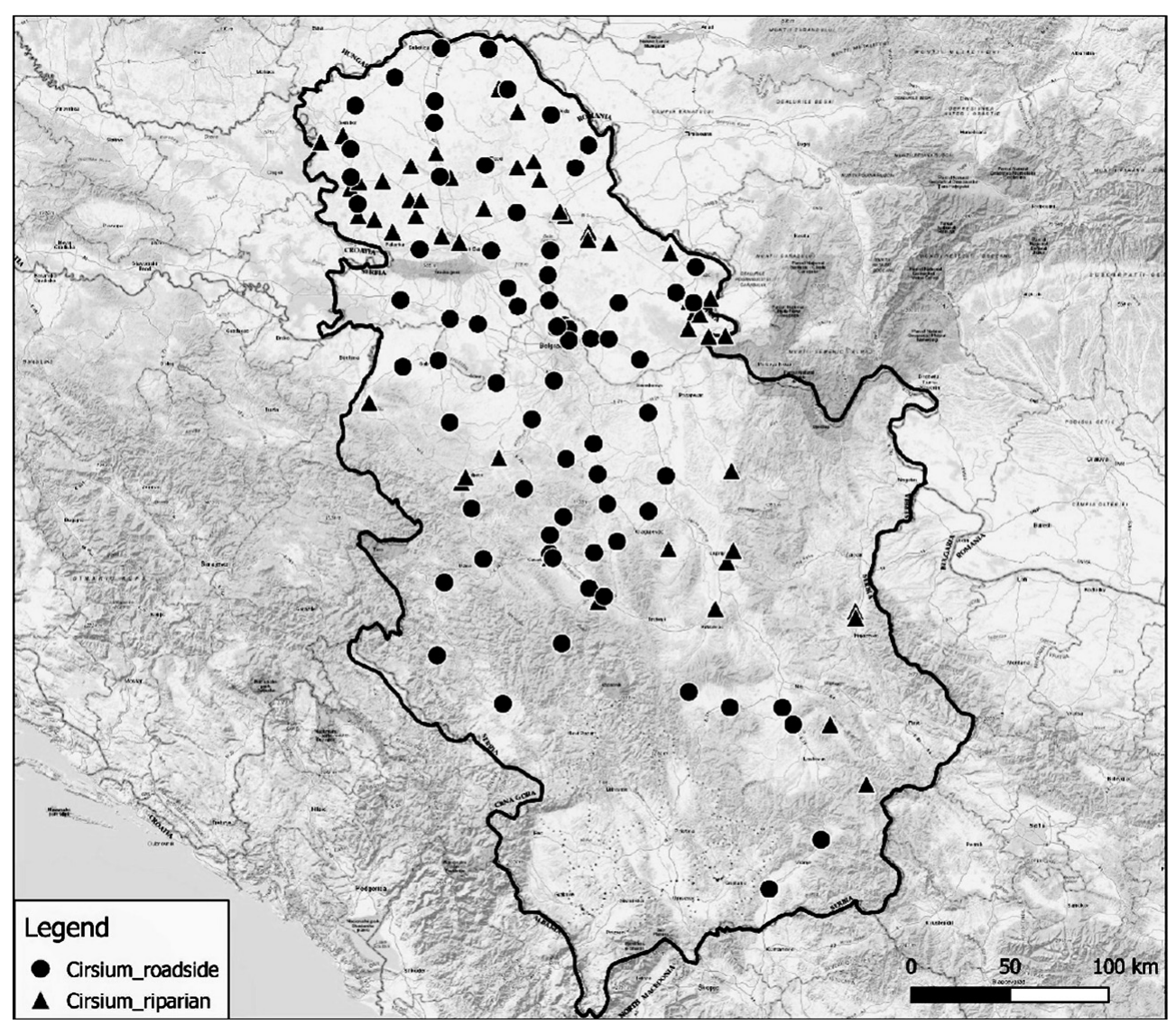

Map 5. Distribution map of Cirsium arvense along the roads and riparian zones of Serbia.

Karta 5. Mapa distribucije Cirsium arvense duž puteva i riparijalnih područja Srbije.

are especially characteristic for the verges of highways. Such a distribution could also result from the ecological preferences of this particular weed species, favoring open, dry and sunny places (Cincović and Kojić, 1976). Additionally, its distribution along the road network could be considered favorable, given that its rhizomes are known to stabilize the soil, preventing erosion events (Cincović and Kojić, 1976).

Flooding (in riparian areas) and nutrient enrichment (on the edges of roads) positively affect the native-exotic species interactions (Qiu et al., 2020). The expected outcome of such external factors could also favor the dominance of generalist and competitive weeds in these frequently disturbed areas. Vanneste et al. (2020) support this opinion, showing that road verges experience an increase in dominance and diversity of generalist species.

Vojvodina Province is a vast agricultural landscape, with high nutrient enrichment of both waterways and roadsides, supplied via drift from the adjacent arable land (Aude et al., 2004). Such nutrient-rich habitats are a significant source of successful invaders worldwide (Hejda 


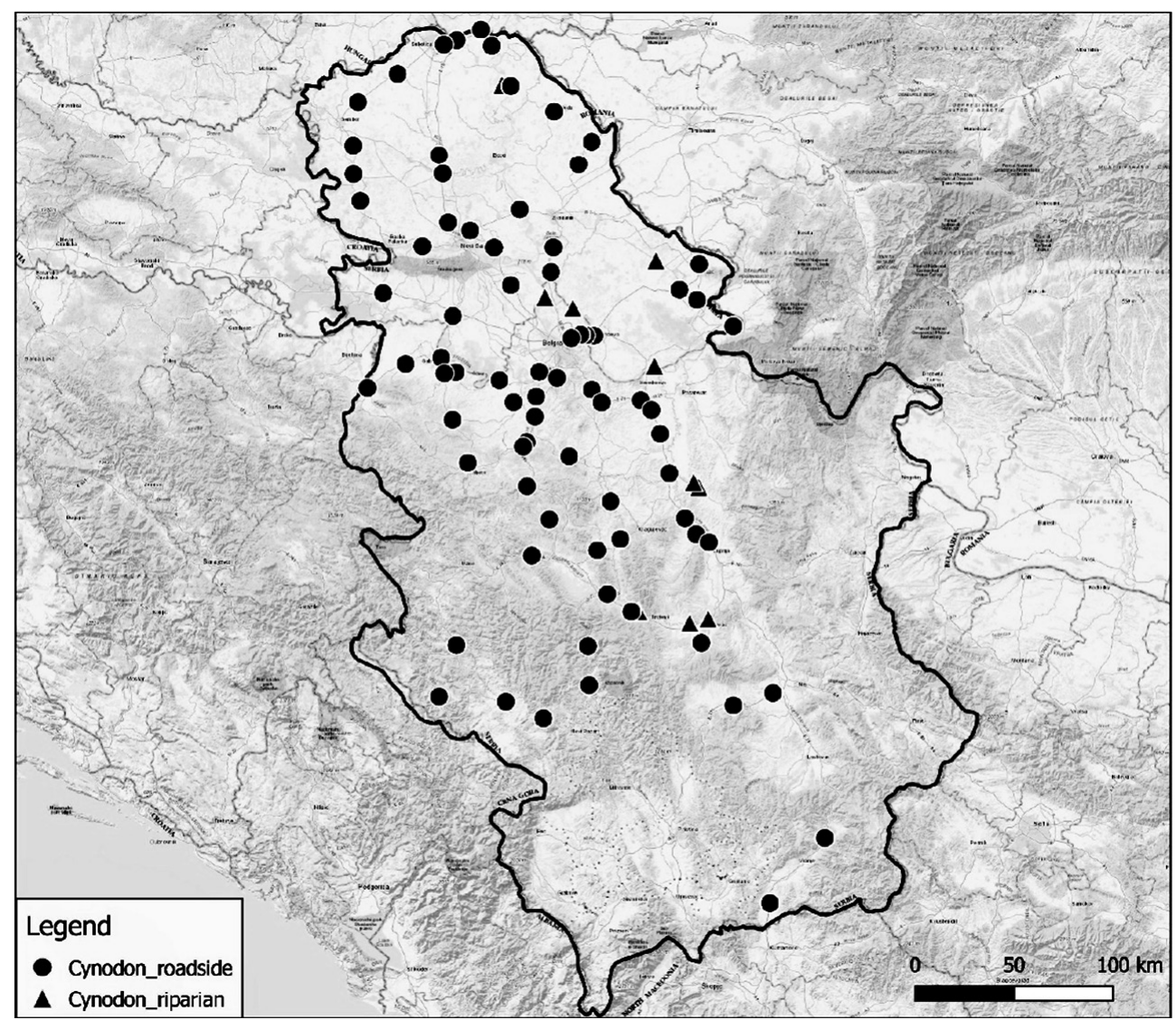

Map 6. Distribution map of Cynodon dactylon along the roads and riparian zones of Serbia.

Karta 6. Mapa distribucije Cynodon dactylon duž puteva i riparijalnih područja Srbije.

et al., 2015), resulting in favorable conditions for the growth and propagation of generalist plant species, such are the selected study species.

A frequency reduction of all five studied weed species in riparian and high-elevation ruderal sites (data not shown, but see Maps 2-6) is in line with one of the main invasion syndromes, which postulates that the spread of plant species along various transport corridors is primarily linked to low and mid-elevations (Novoa et al., 2020). An increased presence of the studied weed species in the Vojvodina Province and within the catchment areas of the Zapadna Morava and Južna Morava rivers can also be related to the degree of urbanization of these areas (especially in the basins of the Zapadna Morava and Nišava rivers). Because urban areas act as hubs for invasion (Reed et al., 2020), transport corridors enable constant pressure on the surrounding agricultural and riparian areas. 


\section{CONCLUSION}

Considering the importance of roads and waterways in the spread of plant species, we aimed to determine the presence of five economically important weed species along these linear corridors in Serbia. Along 250 riparian and 180 roadside sites, the most frequent species is $C$. arvensis, predominantly by road networks. Following species, L. serriola is evenly distributed between roads and waterways, while $C$. album is more frequent at riparian sites. $C$. arvense and $C$. dactylon are less frequent than the mentioned species, primarily associating with roadside vegetation. The distribution of studied weed species is primarily conditioned by their ecological characteristics, which define this habitat preference.

\section{ACKNOWLEDGEMENTS}

The authors acknowledge the support of the Ministry of Science, Education and Technological Development of the Republic of Serbia (this research was conducted within the framework of the Project TR31018 and Contracts No. 451-03-9/2021-14/200010 and 451-03-9/202114/200125). Part of the field work was also funded through a Contract for cooperation between the PE "Putevi Srbije" and the Institute for Plant Protection and Environment, for which we are also grateful.

\section{REFERENCES}

Aguiar, F. C., Ferreira, M. T., Albuquerque, A., Bernez, I.: Invasibility patterns of knotgrass (Paspalum distichum) in Portuguese riparian habitats. Weed Technology, 19 (3), 509-516, 2005.

Arredondo, T. M., Marchini, G. L., Cruzan, M. B.: Evidence for human-mediated range expansion and gene flow in an invasive grass. Proceedings of the Royal Society B: Biological Sciences, 285, 20181125, 2018.

Aude, E., Tybirk, K., Michelsen, A., Ejrnoes, R., Hald, A. B., Mark, S.: Conservation value of the herbaceous vegetation in hedgerows-does organic farming make a difference? Biological Conservation, 118 (4), 467478, 2004.

Auestad, I., Rydgren, K., Austad, I.: Road verges: potential refuges for declining grassland species despite remnant vegetation dynamics. Annales Botanici Fennici, 48 (4), 289-303, 2011.

Bajwa, A. A., Zulfiqar, U., Sadia, S., Bhowmik, P., Chauhan, B. S.: A global perspective on the biology, impact and management of Chenopodium album and Chenopodium murale: two troublesome agricultural and environmental weeds. Environ Science and Pollution Research, 26, 5357-5371, 2019.

Benedetti, Y., Morelli, F.: Spatial mismatch analysis among hotspots of alien plant species, road and railway networks in Germany and Austria. PLoS One, 12 (8), e0183691, 2017.

Burkart, M.: River corridor plants (Stromtalpflanzen) in Central European lowland: a review of a poorly understood plant distribution pattern. Global Ecology and Biogeography, 10 (5), 449-468, 2001.

Chadha, A., Florentine, S. K., Chauhan, B. S., Long, B., Jayasundera, M.: Influence of soil moisture regimes on growth, photosynthetic capacity, leaf biochemistry and reproductive capabilities of the invasive agronomic weed; Lactuca serriola. PloS One, 14 (6), e0218191, 2019. 
Christen, D. C., Matlack, G. R.: The habitat and conduit functions of roads in the spread of three invasive plant species. Biological Invasions, 11 (2), 453-465, 2009.

Cincović, T., Kojić, M.: Rod Cynodon Rich in Pers. 1805. U: Flora SR Srbije VIII. Josifović, M. (Ed.). SANU, Beograd, 1976, str. 299-301.

Cottet, M., Rivière-Honegger, A., Vaudor, L., Colombain, L., Dommanget, F., Evette, A.: The end of a myth: solving the knotweeds invasion "problem". Anthropocene, 30, 100240, 2020.

Dodamani, B. M., Das, T. K.: Density and nitrogen effects on interference and economic threshold of common lambsquarters in wheat. Journal of Pest Science, 86 (3), 611-619, 2013.

Fernandes, M. R., Aguiar, F. C., Silva, J. M., Ferreira, M. T., Pereira, J. M.: Spectral discrimination of giant reed (Arundo donax L.): A seasonal study in riparian areas. ISPRS Journal of Photogrammetry and Remote Sensing, 80, 80-90, 2013.

Funes, G., Basconcelo, S., Díaz, S., Cabido, M.: Seed size and shape are good predictors of seed persistence in soil in temperate mountain grasslands of Argentina. Seed Science Research, 9 (4), 341-345, 1999.

Gerber, E., Krebs, C., Murrell, C., Moretti, M., Rocklin, R., Schaffner, U.: Exotic invasive knotweeds (Fallopia spp.) negatively affect native plant and invertebrate assemblages in European riparian habitats. Biological Conservation, 141 (3), 646-654, 2008.

Hejda, M., Chytrý, M., Pergl, J., Pyšek, P.: Native-range habitats of invasive plants: are they similar to invadedrange habitats and do they differ according to the geographical direction of invasion? Diversity and Distributions, 21 (3), 312-321, 2015.

Hejda, M., Sádlo, J., Kutlvašr, J., Petřík, P., Vítková, M., Vojik, M., Pyšek, P., Pergl, J.: Impact of invasive and native dominants on species richness and diversity of plant communities. Preslia, 93, 181-201, 2021.

Jakobsson, S., Bernes, C., Bullock, J. M., Verheyen, K., Lindborg, R.: How does roadside vegetation management affect the diversity of vascular plants and invertebrates? A systematic review. Environmental Evidence, 7 (1), 17, 2018.

Johansson, M. E., Nilsson, C., Nilsson, E.: Do rivers function as corridors for plant dispersal? Journal of Vegetation Science, 7 (4), 593-598, 1996.

Kent, M.: The description of vegetation in the field. In: Kent, M. (Ed.), Vegetation Description and Data Analysis, A Practical Approach, $2^{\text {nd }}$ edition. Wiley-Blackwell, 2012, p. 66.

Kojić, M., Popović, R., Karadžić, B.: Vaskularne biljke Srbije kao indikatori staništa. Institut za istraživanja u poljoprivredi „Srbija”, Institut za biološka istraživanja „Siniša Stanković”, Beograd, 1997.

Laurance, W. F., Arrea, I. B.: Roads to riches or ruin? Science, 358 (6362), 442-444, 2017.

Liu, X., Blackburn, T. M., Song, T., Li, X., Huang, C., Li, Y.: Risks of biological invasion on the belt and road. Current Biology, 29 (3), 499-505, 2019.

Meseldžija, M., Rajković, M., Dudić, M., Vranešević, M., Bezdan, A., Jurišić, A., Ljevnaić-Mašić, B.: Economic Feasibility of Chemical Weed Control in Soybean Production in Serbia. Agronomy, 10 (2), 291, 2020.

Naiman, R. J., Decamps, H.: The ecology of interfaces: riparian zones. Annual Review of Ecology and Systematics, 28 (1), 621-658, 1997.

Naiman, R. J., Decamps, H., Pollock, M.: The role of riparian corridors in maintaining regional biodiversity. Ecological Applications, 3 (2), 209-212, 1993.

Novoa, A., Richardson, D. M., Pyšek, P., Meyerson, L. A., Bacher, S., Canavan, S., Catford, J. A., Čuda, J., Essl, F., Foxcroft, L. C., Genovesi, P.: Invasion syndromes: A systematic approach for predicting biological invasions and facilitating effective management. Biological Invasions, 22, 1801-1820, 2020.

Pyšek, P., Prach, K.: Invasion dynamics of Impatiens glandulifera - a century of spreading reconstructed. Biological Conservation, 74 (1), 41-48, 1995.

Qiu, S., Liu, S., Wei, S., Cui, X., Nie, M., Huang, J., He, Q., Ju, R. T., Li, B.: Changes in multiple environmental factors additively enhance the dominance of an exotic plant with a novel trade-off pattern. Journal of Ecology, 108 (5), 1989-1999, 2020. 
Radovanović, N., Kuzmanović, N., Vukojičić, S., Lakušić, D., Jovanović, S.: Floristic diversity, composition and invasibility of riparian habitats with Amorpha fruticosa: A case study from Belgrade (Southeast Europe). Urban Forestry \& Urban Greening, 24, 101-108, 2017.

Reed, E. M. X., Serr, M. E., Maurer, A. S., Reiskind, M. B.: Gridlock and beltways: the genetic context of urban invasions. Oecologia, 192, 615-628, 2020.

Richardson, D. M., Holmes, P. M., Esler, K. J., Galatowitsch, S. M., Stromberg, J. C., Kirkman, S. P., Pyšek, P., Hobbs, R. J.: Riparian vegetation: degradation, alien plant invasions, and restoration prospects. Diversity and Distributions, 13 (1), 126-139, 2007.

Riis, T., Kelly-Quinn, M., Aguiar, F. C., Manolaki, P., Bruno, D., Bejarano, M. D., Clerici, N., Fernandes, M. R., Franco, J. C., Pettit, N., Portela, A. P.: Global overview of ecosystem services provided by riparian vegetation. Bioscience, 70 (6), 501-514, 2020.

Rød-Eriksen, L., Skrutvold, J., Herfindal, I., Jensen, H., Eide, N. E.: Highways associated with expansion of boreal scavengers into the alpine tundra of Fennoscandia. Journal of Applied Ecology, 57 (9), 1861-1870, 2020.

Safdar, M. E., Hayyat, M. S., Maajid, M. Z., Nadeem, M., Ali, A.: Estimation of economic threshold of Convolvulus arvensis L. weed in wheat (Triticum aestivum L.). Pakistan Journal of Weed Science Research, 25 (1), 17-26, 2019.

Slavnić, Ž.: Rod Chenopodium L. 1753. U: Flora SR Srbije III. Josifović, M. (Ed.). SANU, Beograd, 1972, str. 22-24.

Stella, J. C., Bendix, J.: Multiple stressors in riparian ecosystems. In: Sabater, S., Elosegi, A., Ludwig, R. (Eds.), Multiple Stressors in River Ecosystems - Status, Impacts and Prospects for the Future. Elsevier, 2019, pp. 81-110.

Valizadeh, N., Birshekari, B.: Determination of economical yield loss threshold of Chenopodium album at interference with rapeseed (Brassica napus). Journal of Food Agriculture Environment, 9, 409-412, 2011.

Vanneste, T., Govaert, S., de Kesel, W., van den Berge, S., Vangansbeke, P., Meeussen, C., Brunet, J., Cousins, S. A., Decocq, G., Diekmann, M., Graae, B. J.: Plant diversity in hedgerows and road verges across Europe. Journal of Applied Ecology, 57 (7), 1244-1257, 2020.

Vrbničanin, S., Malidža, G., Stefanović, L., Elezović, I., Stanković-Kalezić, R., Marisavljević, D., JovanovićRadovanov, K., Pavlović, D., Gavrić, M.: Distribucija nekih ekonomski štetnih, invazivnih i karantinskih korovskih vrsta na području Srbije, II deo - prostorna distribucija i zastupljenost devet korovskih vrsta. Biljni lekar, 36 (6), 408-417, 2008a.

Vrbničanin, S., Malidža, G., Stefanović, L., Elezović, I., Stanković-Kalezić, R., Jovanović-Radovanov, K., Marisavljević, D., Pavlović, D., Gavrić, M.: Distribucija nekih ekonomski štetnih, invazivnih i karantinskih korovskih vrsta na području Srbije. III deo: Prostorna distribucija i zastupljenost osam korovskih vrsta na području Srbije. Biljni lekar, 36 (6), 408-418, 2008b.

Weaver, S., Cluney, K., Downs, M., Page, E.: Prickly lettuce (Lactuca serriola) interference and seed production in soybeans and winter wheat. Weed Science, 54 (3), 496-503, 2006.

Wehling, S., Diekmann, M.: Importance of hedgerows as habitat corridors for forest plants in agricultural landscapes. Biological Conservation, 142 (11), 2522-2530, 2009.

Weidlich, E. W., Flórido, F. G., Sorrini, T. B., Brancalion, P. H.: Controlling invasive plant species in ecological restoration: a global review. Journal of Applied Ecology, 59 (9), 1806-1817, 2020.

Xiang, H., Zhang, Y., Richardson, J. S.: Importance of riparian zone: effects of resource availability at land-water interface. Riparian Ecology and Conservation, 3 (1), 3-17, 2017.

Yarnia, M.: Comparison of field bindweed (Convolvulus arvensis L.) and bermuda grass (Cynodon dactylon L.) organs residues on yield and yield components of bread wheat (Triticum aestivum L.). Advances in Environmental Biology, 4 (3), 414-421, 2010. 


\section{Zastupljenost ekonomski značajnih korovskih vrsta u vegetaciji duž riparijalnih staništa i puteva na području Srbije}

\section{REZIME}

Koridori kao što su vodotokovi i mreža puteva omogućavaju prodor invazivnih i ekonomski značajnih korovskih vrsta. Promenljivi uslovi staništa u riparijalnim zonama i obogaćivanje ivica puteva nutrijentima podstiču uspostavljanje i širenje ovih vrsta, što može imati negativne posledice na obližnje obradive površine i može dovesti do značajnih gubitaka u prinosima. Cilj istraživanja bio je da se dokumentuje prisustvo i zastupljenost pet odabranih korovskih vrsta (Chenopodium album, Cirsium arvense, Convolvulus arvensis, Cynodon dactylon i Lactuca serriola) duž ovih linearnih koridora. Lokaliteti duž vodotokova su istraživani u periodu 2013-2016. godine, a duž mreže puteva tokom 2018. i 2019. godine. Na svakom lokalitetu prisustvo korovskih vrsta je beleženo na transektima dužine $100 \mathrm{~m}$, čime je u istraživanje uključeno ukupno 250 lokaliteta duž vodotokova i 180 duž puteva. Najčešće zabeležena vrsta je C. arvensis, zatim L. serriola i $C$. album, dok su C. arvense i $C$. dactylon bile manje zastupljene. Osnovna karakteristika istraživanih vrsta je njihova preferencija prema staništima duž puteva, sa izuzetkom vrste C. album, koja je u većoj meri zastupljena u riparijalnim područjima.

Ključne reči: koridor širenja, korov, putevi, vodotokovi, Srbija. 